Article

\title{
Losing in the Polls, Time Pressure, and the Decision to Go Negative in Referendum Campaigns
}

\author{
Alessandro $\mathrm{Nai}^{1, *}$ and Ferran Martínez i Coma ${ }^{2}$ \\ ${ }^{1}$ Amsterdam School of Communication Research, University of Amsterdam, 1018 WV Amsterdam, The Netherlands; \\ E-Mail: a.nai@uva.nl \\ ${ }^{2}$ Griffith Business School, Griffith University, Nathan, QLD 4111, Australia; E-Mail: f.martinezcoma@griffith.edu.au \\ * Corresponding author
}

Submitted: 20 December 2018 | Accepted: 2 May 2019 | Published: 27 June 2019

\begin{abstract}
Why do parties and candidates decide to go negative? Research usually starts from the assumption that this decision is strategic, and within this framework two elements stand out: the prospect of electoral failure increases the use of negative campaigning, and so does time pressure (little reaming time to convince voters before election day). In this article, we contribute to this framework by testing two new expectations: (i) political actors are more likely to go negative when they face unfavourable competitive standings and voting day is near; and (ii) they are less likely to go negative when they faced a substantive degradation in their competitive standing over the course of the campaign. We test these expectations on a rich database of newspaper ads about national referenda in Switzerland and provide preliminary empirical evidence consistent with those expectations. The results have important implications for existing research on the strategic underpinnings of campaigning and political communication.
\end{abstract}

\section{Keywords}

anxiety; advertisement timing; competitive standing; direct democracy; polls; strategic behaviour; Switzerland; negative campaigning

Issue

This article is part of the issue "The Politics, Promise and Peril of Direct Democracy", edited by Todd Donovan (Western Washington University, USA).

(C) 2019 by the authors; licensee Cogitatio (Lisbon, Portugal). This article is licensed under a Creative Commons Attribution 4.0 International License (CC BY).

\section{Introduction}

Negative campaigning - that is, the use of messages intended to attack political rivals instead of promoting one's own ideas and record-matters. Existing evidence suggests that the use of attacks during election campaigns have a wide range of effects, for instance on voters' information memorability and information search (Lau, 1982; Lau \& Redlawsk, 2015), election outcomes (Lau \& Pomper, 2004), turnout (Ansolabehere \& lyengar, 1995; Nai, 2013), support and affect for the attacker and the sponsor (Banda \& Windett, 2016), issue ambivalence and vote consistency (Lanz \& Nai, 2015; Nai, 2014), political "mood" and cynicism (Yoon, Pinkleton, \& Ko, 2005), and so forth. Research on what drives parties and can- didates to "go negative" also has flourished in recent years (Nai \& Walter, 2015). This research starts from the assumption that the decision for competing parties to attack their rivals is strategic, and that threy operate a trade-off between benefits (e.g., degraded evaluation of the opponent in the eyes of the voters, or reduced mobilization of undecided voters potentially in favour of the opponent) and costs (potential "backlash" effects, such as reduction in support for the sponsor in the eyes of the voter, as these latter usually dislike negative messages).

In deciding whether to go negative, two elements are particularly relevant: the competitive standing of actors, that is, if they are facing the prospect of electoral failure (or are instead ahead in the race); and the advertisement timing, that is, how much time is left before election 
day. Existing literature shows that unfavourable standings drive the use of attacks (e.g., Skaperdas \& Grofman, 1995; Walter, van der Brug, \& van Praag, 2014). Strong evidence also exists that as the election day draws near, the frequency of negative messages increases substantially (e.g., Freedman \& Goldstein, 2002; Haynes \& Rhine, 1998; Ridout \& Holland, 2010). We still, however, lack systematic evidence about how these two major drivers interact and, more specifically, about how the dynamics of competitive standings affect the use of attack messages (however see Blackwell, 2013). Do unfavourable competitive standings create even stronger incentives to go negative at the end of the campaign? And what happens when a party faces a substantive loss of popular support over the campaign? With this in mind, we discuss and test two new expectations: 1) political actors are more likely to go negative when they are lagging behind in the polls and election day is near (frantic loser hypothesis); and 2) political actors are less likely to go negative when they faced a substantive degradation in their competitive standing over the course of the campaign (anxiety hypothesis). Do competing candidates "plan all of their rallies, write all of their speeches, and film all of their advertisements at the beginning of a campaign, then sit back and watch them unfold until Election Day? Clearly this is absurd" (Blackwell, 2013, p. 504).

Our article contributes to the emerging literature assessing the dynamics of election campaigns, starting from the assumption that competing parties and candidates adjust their strategies based on the evolution of the information they are exposed to.

We test our dynamic expectations on a rich database of campaign ads published in newspapers before federal referenda in Switzerland between 1999 and 2012. Comparing with the USA, undoubtedly the most studied case when it comes to negative campaigning, trends for Switzerland will probably represent a conservative estimate. Referenda are different than elections, as competition is not between opposing candidates but between camps supporting opposing policy proposals. This, as we argued elseqhere (Nai, 2013), probably makes that "character assasinations" are less frequent than in (first-pastthe-post) elections. Second, Swiss election campaigns are still not fully professionalized, nor "Americanized" (Marquis \& Bergman, 2009); Swiss campaigns rarely rely on consultants, spin-doctors or opposition research techniques, which have been shown to increase the use of negative advertising (Geer, 2012). Third, culturally, whereas in the USA negativity is endemic to the political game, in Switzerland political attacks are decidedly less frequent and at odds with the deep-rooted tradition of consensual agreements and cordial decision-making and governance (but see Hänggli \& Häusermann, 2015). Fourth, voting via postal ballots in the weeks before the election is very common in Swiss referenda, which implies that a non-negligible share of the electorate is de facto uninfluenced by campaign dynamics because they already voted. Nonetheless, the share of undecided voters making up their minds at the very last minutewho have been shown to be particularly affected by election campaigns (Nai \& Walter, 2015)-is still important, and thus there is no reason to believe that campaign dynamics should not play a major role in Switzerland as well, albeit probably a subdued one in international comparison. Indeed, we are not the first to have studied campaign dynamics in Swiss referenda. For instance, evidence exists that intense referendum campaigns increase the interest and mobilization of voters (Kriesi, 2005; Marquis \& Bergman, 2009) and are more likely to affect voting choices (Sciarini \& Tresch, 2011); at the same time, campaigns are able to alter the nature of the media debate, as the content of media frames about the referenda tends to reflect issue framing by the campaigns (Hänggli \& Kriesi, 2010). More recently, some studies have assessed more specifically the use of negative campaigning techniques in Swiss referendum campaigns (e.g., Bernhard, 2012; Lanz \& Nai, 2015; Nai, 2013, 2014, 2015; Nai \& Sciarini, 2018). However, to the best of our knowledge, this article is the first attempt at studying the dynamics of competitive standing in polls and use of negative campaigning during referenda, in Switzerland and elsewhere.

Political attacks can broadly be classified into two main types: person-based and policy-based attacks (e.g., Benoit, 1999; Lau \& Pomper, 2004). Policy attacks focus on the shortcomings of the opponents' program, record or policy propositions, whereas character attacks focus on the opponents themselves-their persona, character, profile, and even physical attributes ("ad hominem attacks"). In this article we focus on character attacks, for two reasons. First, from a logistical standpoint, it makes little sense to study the presence and effects of policy attacks in a direct-democratic setting; the very nature of referendum campaigns is all about criticizing policy propositions of the opposing camp (Nai, 2013). Second, from a theoretical standpoint, personal attacks are more likely to generate backlash effects (Budesheim, Houston, \& DePaola, 1996; Carraro \& Castelli, 2010), probably because citizens dislike them even more than policy attacks (e.g., Fridkin \& Kenney, 2011; Nai \& Walter, 2015). Thus, personal attacks potentially provide a fertile ground to test our new hypotheses, which all start form the premise that actors strategically assess the chances of a potential backlash before going negative.

\section{Competitive Standing, Advertisement Timing, and the Chances to Go Negative}

Why do parties and candidates decide to run negative campaigns? Modern campaigns are supported by a professional apparatus. It relies on public opinions consultants, internally-run opinion polling, media consultants, research and analysis divisions, fundraising consultants, opposition research to uncover dirty business of opponents and disliked candidates, multimedia consultants, social media specialists, and so forth (see, e.g., Plasser, 
2000). This creates a situation in which the decision to "go negative" is by all likelihood a strategic one, and political actors weigh uncertain benefits against potential costs when deciding whether to attack their opponents (Lau \& Pomper, 2004). On the benefits side, political actors "go negative" in an attempt to attract undecided voters or to diminish positive feelings for opposing candidates or parties, thus indirectly increasing their popular support (Budesheim et al., 1996; Lau, Siegelman, \& Rovner, 2007). On the costs side, running excessively negative campaigns is considered to be a potentially dangerous strategy, as attacks are unpopular and generally disliked by the public (Fridkin \& Kenney, 2011). Thus, attackers face the risk that thir messages will "backlash" and generate negative feelings towards them instead of towards the target (Garramone, 1984; Johnson-Cartee \& Copeland, 1991; Roese \& Sande, 1993).

Within this strategic framework, two elements stand out as particularly relevant: the competitive standing of competitors, that is, if they are lagging behind or are ahead in the race; and the advertisement timing, that is, how much time in the campaign is left to attract voters (or scare voters away from the opposite camp). First, the competitive standing of parties and candidates (Haynes \& Rhine, 1998) is a good predictor for the chances they will run negative campaigns. Pre-election polls are a central component of the "horserace" framing in political journalism (e.g., Broh, 1980; lyengar, Norpoth, \& Hahn, 2004), but their direct effect on election results is still debated. Some scholars argue that identifying a winner in polls acts as a powerful heuristic to motivate undecided voters to support a candidate likely to win in the election, thus not wasting their vote (bandwagon effect; Marsh, 1985), in which cases opinion polls can be seen as "self-fulfilling prophecies" (Rothschild \& Malhotra, 2014); others argue instead that polls can provide a boost for the loser, as people tend to like "underdogs" (Vandello, Goldschmied, \& Richards, 2007). Whatever their direct effect on voters, it is incontestable that preelection polls provide vital information to campaigners to (re)shape their communication strategies. The prospect of electoral failure has been shown to trigger incentives for attack politics (Harrington \& Hess, 1996; Skaperdas \& Grofman, 1995; Walter et al., 2014). Positive campaigning is principally used to attract and entice voters, whereas:

Negative campaigning is used to reduce the support of the opponent...[Thus], the one lagging behind in the polls has not succeeded in attracting undecided voters and, therefore, has to scare off the opponent's voters to stand a better chance. (Elmelund-Præstekær, 2010, p. 141)

In addition, actors lagging behind have little to lose-and much to gain - from a negative strategy. They are, therefore, more willing the bear the risk of "backlash effect", i.e., the risk that negative campaigning might "scare off" voters in the attacker camp (Brooks \& Murov, 2012; Walter, 2012). By contrast, actors who are expected to succeed are less likely to rely on negative campaigning: As potential winners they feel much more concerned by the possible backlash effect; for them, the cost-benefit calculation should result in a risk-adverse strategy.

Second, the advertisement timing is also a good predictor of the tone of the campaign: as the election day draws near, the frequency of negative messages is likely to increase (Damore, 2002; Haynes \& Rhine, 1998; Freedman \& Goldstein, 2002; Ridout \& Holland, 2010). The rationale for this is threefold. First, parties and candidates run campaigns to inform voters about their propositions, which should strategically come first:

At the outset of a campaign, it may be more effective for candidates to provide voters with information about who they are and what issues are important to them. If candidates attack early, they are unable to define themselves to voters because all they are communicating is negative information about their opponents. (Damore, 2002, p. 672)

In this sense, attacks are more likely to appear towards the end of the campaign, in order to increase voters' support once they are saturated with positive information (Damore, 2002; Elmelund-Præstekær, 2011; Peterson \& Djupe, 2005). Second, as a consequence of the first rationale, negative campaigning should be more effective when the parties and candidates are considered credible on the issues at stake. Thus, "by waiting to go negative until after they have established themselves in the mind of voters, candidates may be perceived as more credible, which may increase the veracity of their attacks" (Damore, 2002, p. 673). Third, late negativity could be especially efficient to capture the attention of the batch of voters who make up their mind at the very last moment. Many undecided voters wait until the last moment to make a decision vote, and negative campaigns have been shown to be particularly effective on undecided voters. Recent research has confirmed that these dynamics also exist in direct democratic contests (Nai \& Sciarini, 2018). Thus:

Hypothesis 1: Unfavourable competitive standings increase the use of negative advertising.

Hypothesis 2: Little remaining time before the vote increases the use of negative advertising.

\section{The Dynamic Effects of Competitive Standing and Advertisement Timing: Two New Expectations}

The strategic relevance of losing in the polls and time pressure for the use of negative campaigning is backed by strong scientific evidence across different countries, electoral systems, and types of contests. However, the existing literature usually relies on static causal inferences where the determinants and the decision to go nega- 
tive are measured at a single point in time (however see Blackwell, 2013). To the best of our knowledge, no existing study has been able to show that the strategic decisions of going negative as a result of a negative competitive standing (i.e., losing in the polls) has a dynamic component and is a function of the advertisement timing.

In this article, we propose and test two new expectations about the dynamics between advertisement timing and an unfavourable competitive standing: i) the reinforcing interaction between competitive standing and advertisement timing; and ii) the effect of a negative evolution of competitive standing over time. Our overall argument can be summarize as follows: during the course of the campaign, competing actors are more likely to go negative when they are lagging behind in the polls and election day is close (frantic loser hypothesis). This should always be the case, unless they faced a substantive loss in poll support; in such a case, we argue that the anxiety resulting in being confronted with a worsening competitive standing makes them adopt a more risk-free approach (anxiety hypothesis). We disentangle these two new hypotheses below.

First, we expect unfavourable competitive standing to play an even greater role when time is running out. Ice hockey games provide a good example for this; as per standard regulations, each competing team can, at any time during the game, "pull the goalie" (i.e., remove that player from the ice) in exchange for an extra attack player. In doing so, the team sacrifices defence over offense: they increase their chances to score, but face at the same time a greater risk as they are, after all, playing with a defenceless net. This scenario, quite frequent in USA and European competitions, is a good example for us here because this "reckless" strategy is usually implemented (i) by the losing team, and (ii) at the end of the game. Another reason why the scenario is a good fit for our case is that sport teams and electoral campaigns have in common highly professionalized managers. In both cases, strategic considerations based on risk-averse principles are likely to guide future actions. In both cases, those who make these decisions face a changing environment and have to adapt their strategies. Both are aware of the advantages and risks of more aggressive strategies. Thus, it should come as no surprise that riskier strategies are undertaken by losers only when no other solution exists. This should incite, strategically, to go negative only as a means of last resort, and especially when risks of backlash are irrelevant because of an already negative standing. Thus:

Hypothesis 3: Negative advertising is especially likely in case of unfavourable competitive standings at the end of the campaign (frantic loser hypothesis).

Second, what happens as the competitive standing of parties and candidates evolves over time? More specifically, is the use of negative advertising influenced by unfavourable new polls? As for the frantic loser hypothesis (H3), this second dynamic also takes into account the interaction between competitive standing and advertisement timing. In this case, we expect an effect of an unfavourable evolution in the polls during the campaign. More specifically, we expect that losing support in the polls over the course of the campaign has a detrimen$t a l$ effect on the use of negative campaigning. The rationale for such expectation comes from the emotional effects of new and surprising information on decision making and, more generally, social and political behaviour. The Affective Intelligence Model (Marcus, 2002; Marcus \& MacKuen, 1993; Marcus, Neuman, \& MacKuen, 2000), on which we base our assumptions, describes two fundamental emotional systems that work in parallel, depending on the specific situation that individuals are confronted with (MacKuen, Marcus, Neuman, \& Keele, 2007). First, the disposition system "generates enthusiasm/satisfaction or depression/frustration as incoming information reports that the execution of one's plans either matches or does not match expectations (or success)" (Brader, 2006, p. 60).

Second, the surveillance system "generates anxiety/unease or relaxation/calm as incoming information suggests it is either safe or potentially unsafe to go about one's business as usual" (Brader, 2006, p. 60). The surveillance system is activated when individuals face new and surprising information, which directly generates unease and anxiety. In our case, this should happen when political actors face a drastic drop in their popular support expressed in pre-electoral polls.

The effects of anxiety on decision-making are largely known: anxiety triggers more careful behaviors, thus potentially reducing the use of aggressive campaign techniques. Anxiety "causes individuals to become more aware of their surroundings, in particular, novel or threatening circumstances [and] stimulates a desire to more fully understand and analyze the source of a potential threat" (Steenbergen \& Ellis, 2006, p. 111). Even more important for our purpose is that anxiety has been shown to increase risk perception and risk aversion (Huddy, Feldman, Taber, \& Lahav, 2005; Lerner \& Keltner, 2001). Anxiety might produce "a sense of uncertainty and lack of control that elevates future judgments of risk [...while also increasing] perceived risk because it heightens the salience of self-relevant negative thoughts" (Huddy et al., 2005, p. 595). If new and threatening information leads to anxiety, and if anxiety leads to a higher chance of adopting risk-averse strategies, then it seems logical to expect that actors who face a drastic loss in public support are more likely to be afraid of backlash effects, thus perhaps thinking twice before going negative. This should be a function of the magnitude of the support lost between polls: the higher the support lost, the higher the anxiety felt, thus the higher the chances of adopting risk-averse strategies, and the lower the chances of going negative. Of course, polling results are subject to a great deal of interpretation when it comes to anticipating a final outcome based from them. Furthermore, it is a well-known phenomenon in Swiss 
referenda that many proposals (especially popular initiatives) are affected by a steady erosion of support over the course of the campaign-which is undoubtedly something that campaigners are aware of and are able to anticipate. Nonetheless, we believe that an argument can be made that even with this in mind campaigners are never shielded from negative surprises when it comes to competitive standings, and that facing a sudden drop in support is very likely to affect the strategic considerations about the content of campaign messages. Thus:

Hypothesis 4: A negative evolution in competitive standings leads to lower chances of using negative advertising over the course of the campaign (anxiety hypothesis).

It is important to note that we assume the evolution of competitive standing $(\mathrm{H} 4)$ as having more profound effects than the interaction between losing and timing $(\mathrm{H} 3)$. Parties and candidates whose competitive standing deteriorates should be less likely to go negative even when they are losing in the polls and time is running out. The literature highlighting the prevalence of emotional reasoning over rational and conscious reasoning provides the argument. Emotional experiences (in our case, anxiety) have a structuring effect on cognitive processes (in our case, the decision to go negative or not; Damasio, 1994). "[T]he weight of opinion in psychology has shifted to a view that these unconscious evaluations are far more active, and hence far more important, than conscious cognitive processing" (Marcus, 2000, p. 231). Especially during decision-making processes, affective evaluations and cognitive processes are two sides of a same process ( $N a i$, Schemeil, \& Marie, 2017), and rational thinking depends on prior emotional evaluations. In other words, underlying emotions are more important than higher rational reasoning. The two new hypotheses can thus be articulated as follows: actors are more likely to go negative when they are lagging behind in the polls and voting day is near ( $\mathrm{H} 3)$, unless they faced a substantive degradation in their competitive standing over the course of the campaign, in which case they are less likely to go negative, ceteris paribus (H4).

\section{Data and Measures}

Political commercials on TV and radio are banned in Switzerland. Although political commercials can be broadcasted elsewhere (e.g., in cinemas and online) the culture of campaigning in Switzerland leads to parties and candidates usually not relying on those type of advertising in elections or referenda. In this context, newspapers ads are virtually the only option for political actors to campaign through mass media and are one of the most important campaign instruments for political parties and interest groups, as well as one of the main sources of information for Swiss voters (Kriesi, 2006). In addition, newspaper ads are a reliable indicator of the intensity, direction, and frame of direct democratic campaigns in Switzerland (Nai, 2013; Sciarini \& Tresch, 2011). In this article we rely on a comprehensive database of all campaign ads published in six Swiss newspapers for all national referenda that have taken place in Switzerland between 1999 and 2012, which includes 121 legal or constitutional amendments (see full list in Appendix). We selected six major Swiss newspapers: Tribune de Genève, Le Temps (French), Neue-Zürcher Zeitung, Tages-Anzeiger (German), Regione, and Giornale del Popolo (Italian). Given the fragmentation of Swiss media market along distinct linguistic regions, two newspapers for each of the three main languages were selected. These newspapers are approximately representative of the main ideological cleavages in each linguistic region (e.g., for the Italianspeaking region the Regione has a center-left editorial line, whereas the Giornale del Popolo is usually considered to be center-right). For these newspapers we collected and content-coded all ads published over the four weeks before each vote between 1999 and 2012. We collected and coded more than 10,000 ads, each of them recommending either supporting or rejecting the amendments. Due to missing data for pre-ballot polls (see below), our analyses are run on a subsample of 67 referenda, for which approximately 7,000 newspaper ads were identified. A manual coding of all ads was undertaken, where we identified for each ad the use of "negative" messages where the ad sponsor explicitly criticized their opponents. If one or more of such attacks were present, the ad was qualified as "negative" (Nai, 2013; Nai \& Sciarini, 2018). The dependent variable is thus binary, where 1 measures the presence of one or more personal attack(s) in the ad. Table A1 in the Appendix lists the percentage of ads with personal attacks for each referendum in our database.

We use representative pre-ballot polls to evaluate the competitive standing of actors (Haynes \& Rhine, 1998). For this, we rely on the polls conducted by the Swiss Broadcasting Corporation (Schweizerische Radiound Fernsehgesellschaft, henceforth SRG) the most important and widely-circulated poll for referenda in Switzerland. The data are gathered though surveys on random samples of Swiss citizens (see Nai \& Sciarini, 2018). The SRG polls are conducted twice before each vote: national trends for the first survey are published six weeks before the vote, whereas trends for the second survey are published two weeks before the vote. Based on these trends, we measure competitive standing comparing the relative support for the "yes" and "no" camps (undecided voters are excluded); ads supporting the camp with the lowest relative score are classified as being in the losing camp, and whereas ads with the higher relative share of support in polls are coded as being in the winning camp. Based on the two polls, three variables are created: the first measures competitive standing for the first poll (six weeks before the vote), the second measures competitive standing for the second survey (two weeks before the vote), and the third 
measures the average competitive standing during the whole campaign (average for both surveys).

Furthermore, comparing the two surveys allows us to measure the evolution of competitive standing. By subtracting for any given camp the share of support in the second survey from the share of support in the first survey, we have a direct measure of the relative loss (or gain) in support during the campaign. As an example, the "yes" camp during the popular initiative "For democratic naturalisations", launched by the far-right Swiss People's Party (Schweizerische Volkspartei, henceforth SVP) and voted in June 2008 , was supported by $48 \%$ of voters in the first survey (thus being virtually in the winning camp, if we take into account that $15 \%$ of voters were still undecided), but only supported by $33 \%$ of voters in the second survey, two weeks before the vote. The "yes" camp for that initiative thus lost $15 \%$ between the two surveys (48-33\%) and was virtually the losing camp after the second survey.

SRG pre-ballot polls are available only for a subset of votes. Over the 121 referenda voted on in Switzerland between 1999 and 2012, SRG polls are available only for 69; furthermore, for six votes out of those 69 only the first survey wave (six weeks before the vote) is available. Our analyses will be run only on the subsets of referenda for which pre-ballot polls are available. The Appendix specifies for which referenda the SRG poll data are available.

Based on the day the ad was published in press we can calculate the time remaining between the publication of the ad and the voting day; in our models, we use a variable that differentiates between the week in which the ad was published (either first, second, third, or fourth and last week of the campaign), which provides a valid proxy of the time pressure the actors are facing when publishing their ads. This variable, in conjunction with the variable measuring competitive standings (losing in the polls) will be used to test for our new H3. The timing of the different data sources used in the article is illustrated in Figure 1. As the figure shows, the first SRG survey ( 6 weeks before the vote) establishes the benchmark in terms of winners and losers used during the first half of the "campaign" measured in our newspaper ads data; we assume that the decision to go "negative" during the first half of the campaign is driven by the knowledge of competitive standings (that is, who is ahead and which camp is lagging behind) provided by this first survey. Half-way during this "campaign", two weeks prior to the vote, the second SRG survey changes the dynamics by re-assessing who the frontrunners (potential winners) and losers are at that specific point in time. It is the change between the two surveys, two weeks before the vote, that drives most of the dynamics of (negative) campaigning studied in this article.

Our models include several controls intended to take into account the specific nature of (Swiss) referenda, as well as additional dimensions of the "race". First, we control for the direction of the ad (i.e., whether the ad supports the "yes" or the "no" camp), which has been shown to partially affect the use of negative advertising (Nai, 2013), and include a variable that discriminates between popular initiatives-bottom-up instruments through which any group can put any issue on the political agenda, and which usually generate more negative campaigns and are less successful (Nai, 2013) - and referendums, called in reaction to an amendment of the law or Constitution by the elites. Controlling for these two factors simultaneously allows us to also control, indirectly, for whether the actor is part of the "challenger" coalition-i.e., endorsing the "no" camp in a popular initiative implies endorsing the camp promoting the status quo against the constitutional challenge. Furthermore, our models control for the presence of personal endorsements of the ad (i.e., whether or not the ad is explicitly endorsed by a public figure, such a politician); good reasons exist to expect anonymous (i.e., not personally endorsed) ads to be more negative, as anonymity uncouples the attacker from potential backlash effects (Brooks \& Murov, 2012; Nai \& Sciarini, 2018). Finally, our models control also for the referendum issue (domestic v. foreign policy), and for overall turnout; the latter is intended as proxy of general saliency of the vote and indirectly controls for the fact that negativity could naturally be higher when the public perceives that the issues at stake are important (which usually translates into higher turnout). Descriptive statistics for all variables in our models are presented in Table 1.

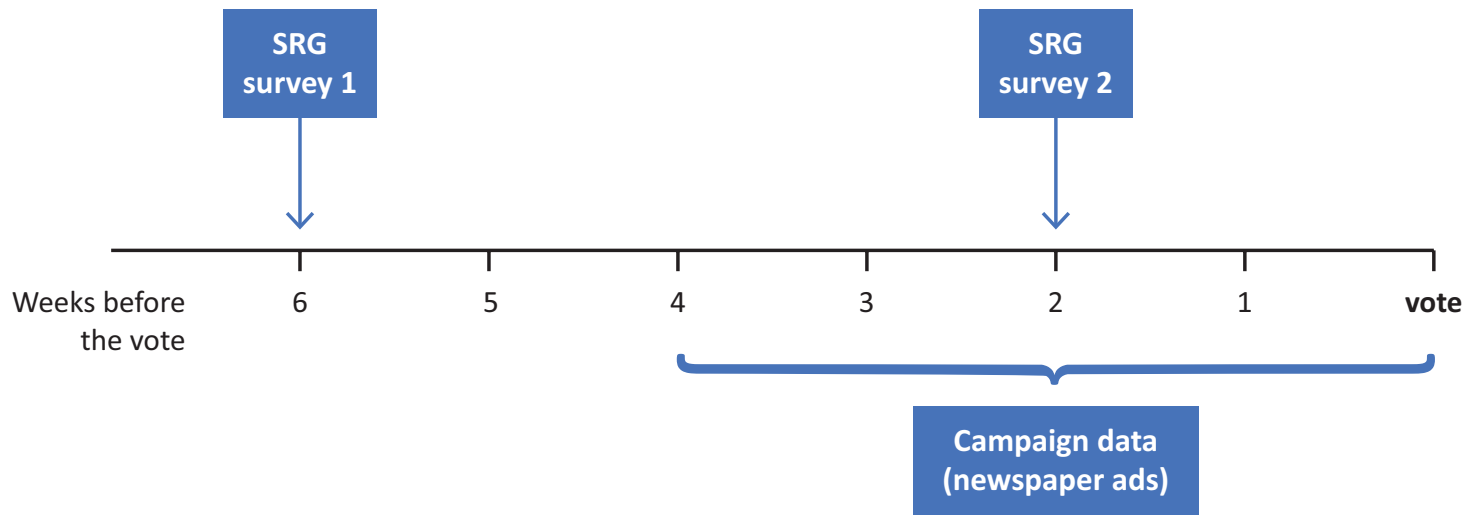

Figure 1. Data and timing of the vote. 
Table 1. Descriptive statistics.

\begin{tabular}{|c|c|c|c|c|c|}
\hline & $\mathbf{N}$ & Mean & Std. dev. & Min & Max \\
\hline Personal attacks in ad ${ }^{a}$ & 6,741 & 0.10 & 0.30 & 0.00 & 1.00 \\
\hline Losing in polls ${ }^{b}$ & 6,741 & 0.46 & 0.50 & 0.00 & 1.00 \\
\hline Total support lost ${ }^{b}$ & 5,718 & -0.02 & 0.08 & -0.28 & 0.23 \\
\hline Week $^{a}$ & 6,741 & 2.62 & 1.05 & 1.00 & 4.00 \\
\hline Explicit endorsement in ad ${ }^{a}$ & 6,741 & 0.32 & 0.47 & 0.00 & 1.00 \\
\hline Ad supports YES vote ${ }^{a}$ & 6,741 & 0.52 & 0.50 & 0.00 & 1.00 \\
\hline Popular initiative ${ }^{a}$ & 6,741 & 0.41 & 0.49 & 0.00 & 1.00 \\
\hline Turnout $^{a}$ & 6,741 & 47.04 & 5.81 & 35.84 & 58.43 \\
\hline Foreign policy issue $^{a}$ & 6,741 & 0.33 & 0.47 & 0.00 & 1.00 \\
\hline
\end{tabular}

Notes: ${ }^{\text {a }}$ Own dataset. ${ }^{\mathrm{b}}$ SRG survey results; gfs.bern.

\section{Analyses and Results}

Our data have a hierarchical structure, where ads are nested within specific referenda. We thus rely on twolevel models where the likelihood to use personal attacks in any given ad (our dependent variable) is regressed on determinants at both the ad and context levels. As the dependent variable is binary we use hierarchical generalized linear models with logit transformations.

Our models are able to go beyond the problem of "single-shot" causal inference, biased because causes and actions are measured in a given single time-point (Blackwell, 2013, p. 505). We take into account the fact that surveys are made public before the publication of ads in newspapers (thus ensuring that the time causality is respected through a naturally lagged independent variable). We are not interested in the effect of negative advertising on election results (or on the evolution of competitive standings during the campaign), but on the reasons why actors decide to go negative. Thus, our models should not excessively suffer from posttreatment bias (i.e., the fact that negativity in earlier phases of the campaign might influence poll results; Blackwell, 2013). Even assuming the worst case scenario in which this happens massively (poll results during the campaign are strongly driven by previous campaign tone), the subsequent behaviour of actors should not be dramatically affected for two reasons: i) actors are not aware if the evolution in polls is due to their previous campaign strategies and thus their behaviour should not be endogenously biased; and ii) referendum campaigns are made up of a multitude of different actors, unlike electoral races, and thus the causal link between any given ad and subsequent poll results for the side they support (yes vs. no) is tenuous at best.

Table 2 shows, first, that the prospect of electoral failure and advertisement timing significantly affect the use of negative advertising. The direct effect of losing in the poll is quite strong, and significantly positive at $p<.001$ (M1). Ceteris paribus, facing a negative competitive standing uncouples parties from the Damocles' sword of potential backlash effects, which increases the appeal of negative advertising. This confirms trends in the USA and beyond (e.g., Damore, 2002; ElmelundPræstekær, 2010; Harrington \& Hess, 1996; Skaperdas \& Grofman, 1995; Walter et al., 2014).

Also, ceteris paribus, when election day draws near political ads are more likely to go negative; ads published during the last week are significantly more negative than ads published during the first week of the campaign (reference category). This is in line with what has been found in several studies (e.g., Damore, 2002; Haynes \& Rhine, 1998; Peterson \& Djupe, 2005; Ridout \& Holland, 2010). The first model, thus, confirms the effects already known in the literature concerning the direct effect of competitive standing and advertisement timing ( $\mathrm{H} 1$ and $\mathrm{H} 2$ ), thus acting as initial benchmark for our additional hypotheses (H3 and $\mathrm{H} 4)$.

Model M2 presents a first test for the joint effect of losing in the polls and advertisement timing, via an interactive term between the two. The interaction effect is significant at $p<.05$, but its magnitude is quite small, as substantiated in Figure 2 via marginal effects.

Models M3 and M4 present additional tests for the joint effect of losing in the polls and advertisement timing. We expected that the simultaneous presence of unfavourable polls and time pressure would trigger the use of personal attacks even more substantively. We expected, in other terms, that losers tend to become frantic when time is running out. Model M3 is run only on ads published within the first two weeks of the campaigns (respectively 4 and 3 weeks before the vote), and thus published after the first SRG poll, but before the second. We expect that ads published in this first half of the campaign are affected by the first survey only. Model M4 is very similar, but run only on ads published in the last two weeks in the campaign ( 2 and 1 weeks before the vote), and thus just after the second SRG poll. We might thus expect that ads published in the last two weeks of the campaigns are especially affected by results of this second poll. Using another sport metaphor, one can think about those two models as follows: M3 estimates a more aggressive behaviour for the losing side during the first half of the game; M4 estimates the same, but for the second half of the game. The fact that models M3 and M4 are run on subsamples of ads is the reason why these mod- 
Table 2. Use of personal attacks by competitive standing and advertisement timing.

\begin{tabular}{|c|c|c|c|c|c|c|c|c|c|c|c|c|}
\hline & \multicolumn{6}{|c|}{ Whole campaign } & \multicolumn{3}{|c|}{$\begin{array}{l}\text { First two weeks } \\
\text { of campaign }\end{array}$} & \multicolumn{3}{|c|}{$\begin{array}{l}\text { Last two weeks } \\
\text { of campaign }\end{array}$} \\
\hline & \multicolumn{3}{|l|}{ M1 } & \multicolumn{3}{|l|}{ M2 } & \multicolumn{3}{|l|}{ M3 } & \multicolumn{3}{|l|}{ M4 } \\
\hline & OR & (Se) & Sig & OR & (Se) & Sig & OR & (Se) & Sig & OR & (Se) & Sig \\
\hline Intercept & 0.00 & $(0.01)$ & $* *$ & 0.00 & $(0.01)$ & $* *$ & 0.08 & $(0.21)$ & & 0.01 & $(0.01)$ & $* *$ \\
\hline Losing in polls & 2.02 & $(0.27)$ & $* * *$ & 3.34 & (9.92) & $* * *$ & & & & & & \\
\hline Losing in polls (survey 1$)^{a}$ & & & & & & & 1.38 & $(0.36)$ & & & & \\
\hline Losing in polls (survey 2$)^{b}$ & & & & & & & & & & 1.63 & $(0.27)$ & $* *$ \\
\hline \multicolumn{13}{|l|}{ Week $^{c}$} \\
\hline - second & 0.95 & $(0.14)$ & & 1.06 & $(0.16)$ & & & & & & & \\
\hline- third & 1.16 & (0.16) & & 1.46 & $(0.26)$ & $*$ & & & & & & \\
\hline — fourth (and last) & 1.34 & $(0.18)$ & $*$ & 1.89 & $(0.41)$ & $* *$ & & & & & & \\
\hline Losing * week & & & & 0.83 & $(0.7)$ & $*$ & & & & & & \\
\hline Endorsement & 0.31 & $(0.04)$ & $* * *$ & 0.31 & $(0.04)$ & $* * *$ & 0.33 & $(0.07)$ & $* * *$ & 0.28 & $(0.05)$ & $* * *$ \\
\hline Ad supports YES vote & 0.85 & (0.11) & & 0.85 & (0.11) & & 0.59 & (0.15) & $*$ & 0.81 & $(0.14)$ & \\
\hline Turnout & 1.05 & $(0.04)$ & & 1.05 & $(0.04)$ & & 0.97 & (0.06) & & 1.05 & $(0.04)$ & \\
\hline Popular initiative & 1.84 & $(0.80)$ & & 1.82 & $(0.80)$ & & 3.33 & (1.85) & $*$ & 1.29 & $(0.49)$ & \\
\hline Foreign policy & 2.72 & $(1.61)$ & $\dagger$ & 2.73 & $(1.62)$ & + & 5.18 & (3.94) & $*$ & 2.23 & (1.07) & $\dagger$ \\
\hline Log Likelihood & -1782 & & & -1780 & & & -729 & & & -1032 & & \\
\hline Rho & 0.40 & $(0.07)$ & & 0.40 & $(0.07)$ & & 0.45 & $(0.08)$ & & 0.28 & $(0.07)$ & \\
\hline $\mathrm{N}$ (ads) & 6,741 & & & 6,741 & & & 2,956 & & & 3,211 & & \\
\hline N (projects voted) & 67 & & & 67 & & & 65 & & & 58 & & \\
\hline $\begin{array}{l}\text { N per group } \\
\text { (min/avg/max) }\end{array}$ & 3/100.6 & 327 & & $3 / 100$. & 1327 & & $1 / 45.5$ & 161 & & $2 / 55.4$ & 193 & \\
\hline
\end{tabular}

Notes: ${ }^{* *} \mathrm{p}<0.001,{ }^{* *} \mathrm{p}<0.01,{ }^{*} \mathrm{p}<0.05,+\mathrm{p}<0.1{ }^{\text {a }}$ Pre-ballot survey 1 published six weeks before voting day. ${ }^{\mathrm{b}}$ Pre-ballot survey 2 published two weeks before voting day. ${ }^{\mathrm{c}}$ Reference category is first week of campaign (4 weeks prior to voting day). Dependent variable is the presence of negativism in the ad (binary variable), random effects logistic regressions run with Stata 14.1. Coefficients are odds ratios, standard errors in parentheses. Model M1 run for ads published during the whole campaign (four weeks prior to voting day). Model M2 run only for ads published during the first two weeks of the campaign (respectively four and three weeks prior to voting day). Model M3 run only for ads published during the last two weeks of the campaign (respectively two and one weeks prior to voting day).

els have, comparatively, a smaller N. The two models provide evidence that suggests the presence of a joint effect between competitive standing and advertisement timing (H3). Even though in both cases the effect of losing in the polls is positive, this effect is stronger and statistically significant only in the last two weeks of the campaign (model M4). The magnitude of this effect, compared with the direct effect of losing in the polls, is substantiated in Figure 3.

Table 3 introduces a new set of analyses. The relevant variable measures how much support the camp has lost between the two SRG polls (total support lost); positive values signal a loss between polls (decreasing popular support), and thus a net degradation in competitive standings, whereas negative values signal a gain in popular support between polls.

We expected degradation in competitive standingsthat is, losing popular support over the duration of the campaign - to decrease the likelihood of negative advertising (H4). Our analyses provide preliminary support for this expectation. When the difference between support in poll 1 (six weeks before the vote) and poll 2 (two weeks before the vote) is positive-that is, when the actor faces deteriorating polls - the probability of running ads with personal attacks decreases significantly. The effect, although positive and significant (as expected) is however not particularly strong, as substantiated in Figure 4 through marginal effects.

The final two models in Table 3 test for the same effect, but by differentiating between ads published by the winning camp (that is, the camp that is still winning in the polls even after results of the second survey are published; M6) and ads published by the losing camp (M7) during the last week of the campaign only (which explains the lower $\mathrm{N}$ overall in the models). The direction of the main results is as expected and are relatively substantial, as illustrated in Figure 5 via marginal effects. Ads published in the last week of the campaign by the winning camp (top panel) are not substantially more negative when the camp lost support between polls. On the other hand (bottom panel), the probability of running ads with personal attacks decreases quite substantially with increasing loss in poll support for the losing camp. This supports our expectation that deteriorating polls makes them more cautious and less likely to go negative on their opponents ( $\mathrm{H} 4)$. 


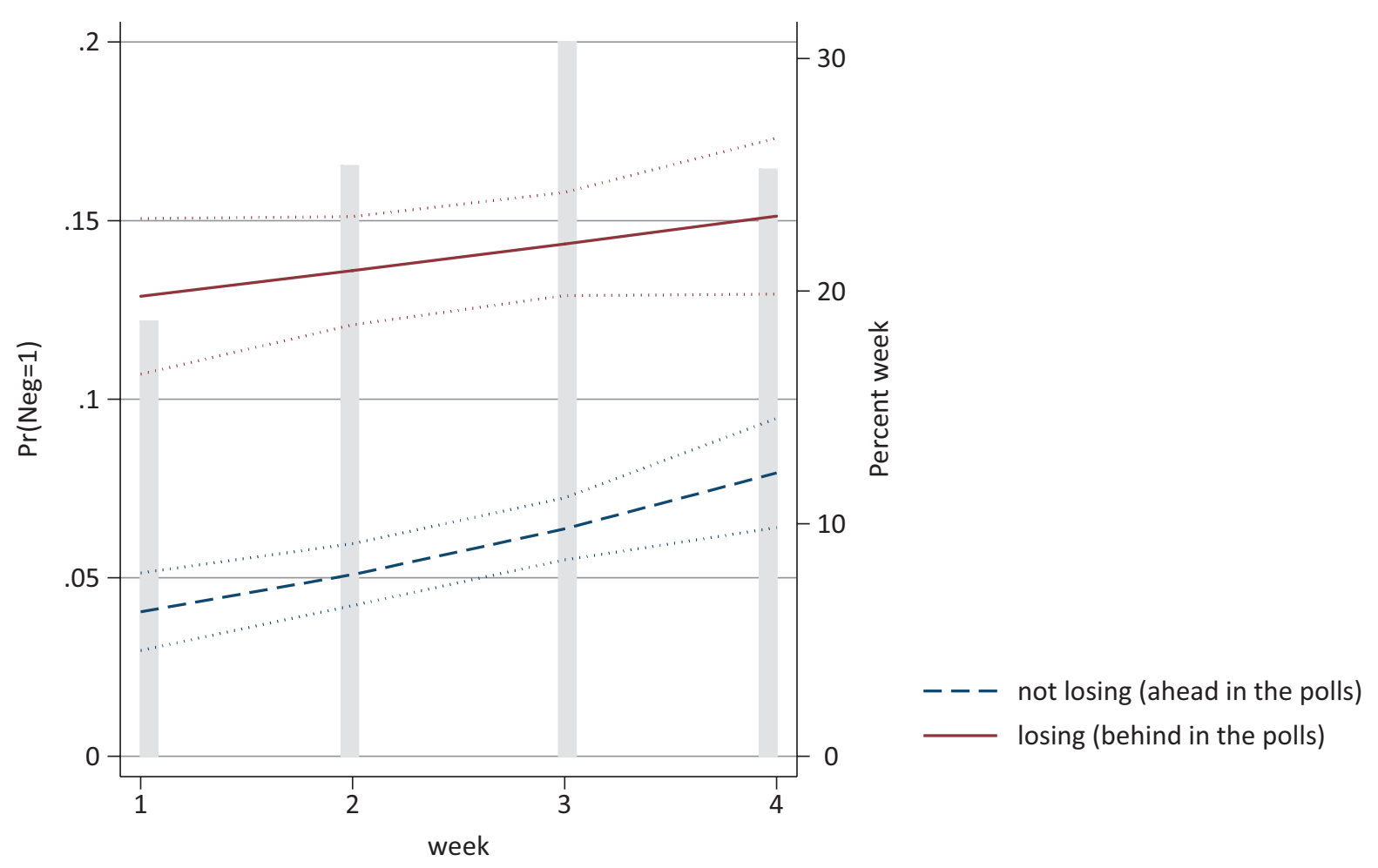

Figure 2. Negative campaigning by losing in polls * week, marginal effects. Notes: Marginal effects with $95 \%$ confidence intervals, based on coefficients in Model M2 (Table 2). The grey bars represent the distribution of the variable "week" (percentage histogram).

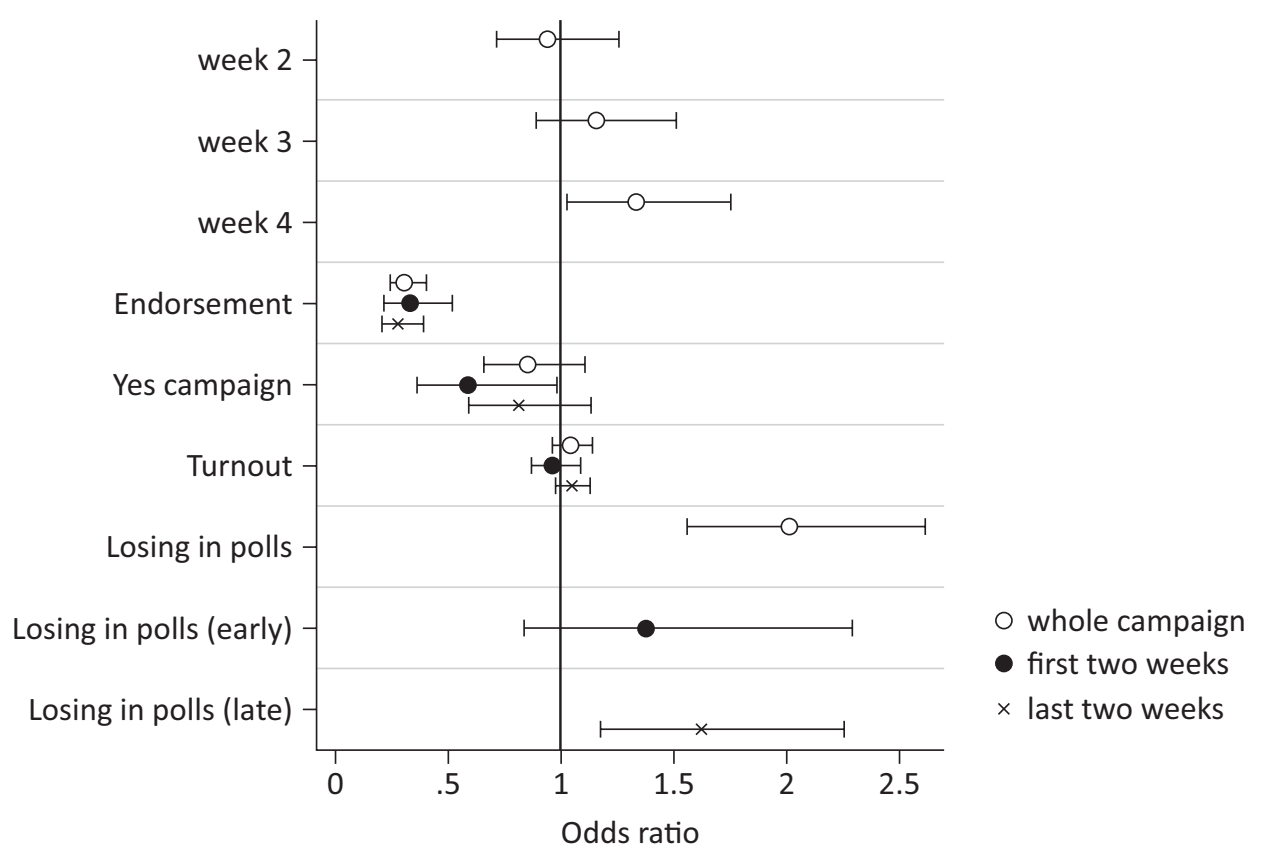

Figure 3. Standardized effects losing in the polls and advertisement timing. Notes: scores represent odds ratios for regression models predicting the presence of personal attacks in ads. Coefficients for the whole campaign are from model M1, coefficients for the first two weeks are from model M3, and coefficients for the last two weeks are from model M4 (Table 2). Coefficients for initiative and foreign policy not presented in the figure to simplify visualization, due to high confidence intervals. 
Table 3. Use of personal attacks by evolution of competitive standing.

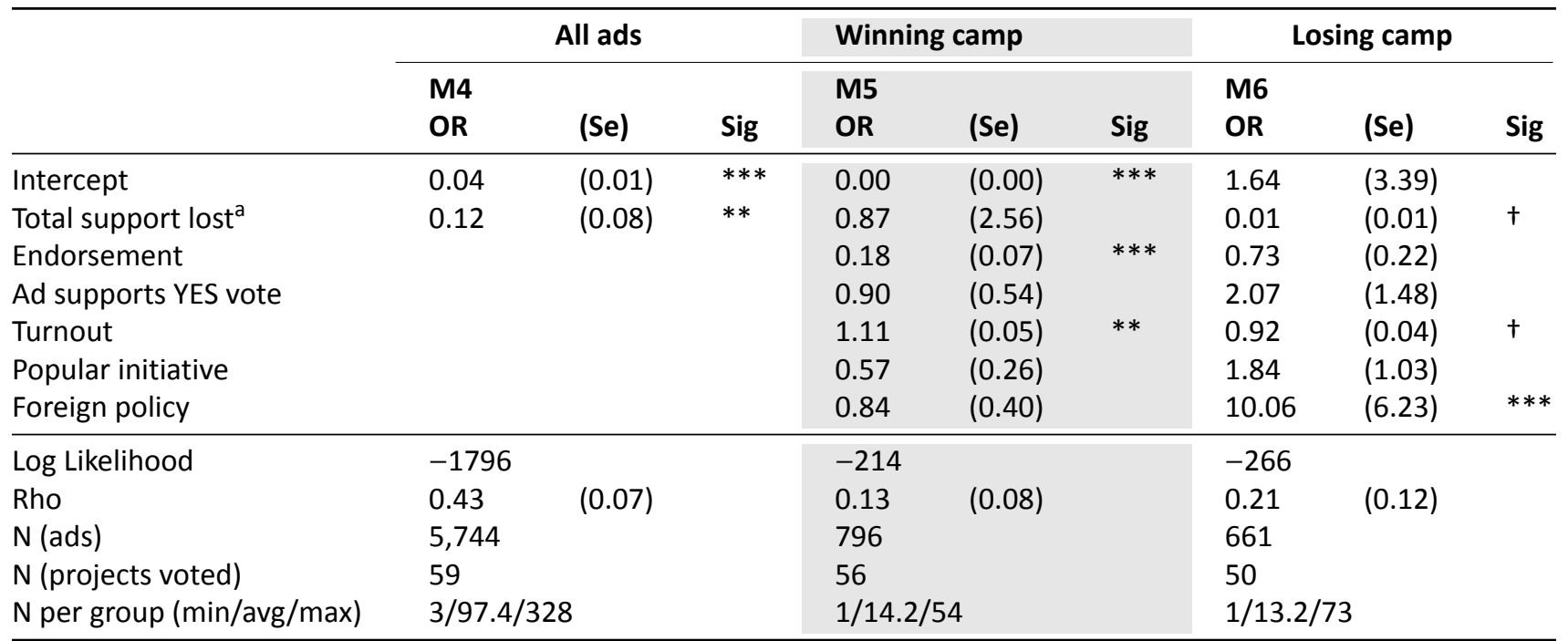

Notes: ${ }^{* * *} \mathrm{p}<0.001,{ }^{* *} \mathrm{p}<0.01,{ }^{*} \mathrm{p}<0.05,+\mathrm{p}<0.1{ }^{\text {a }}$ Total support lost measures the difference in support between Survey 1 (six weeks before the vote) and Survey 2 (two weeks before the vote). Thus, positive values mean that the camp lost support between Survey 1 and Survey 2, whereas negative values mean that the camp gained support between Survey 1 and Survey 2. Dependent variable is the presence of negativism in the ad (binary variable), random effects logistic regressions run with Stata 14.1. Coefficients are odds ratios, standard errors in parentheses. All models run only for ads published during the last week of the campaign (one week prior to voting day).

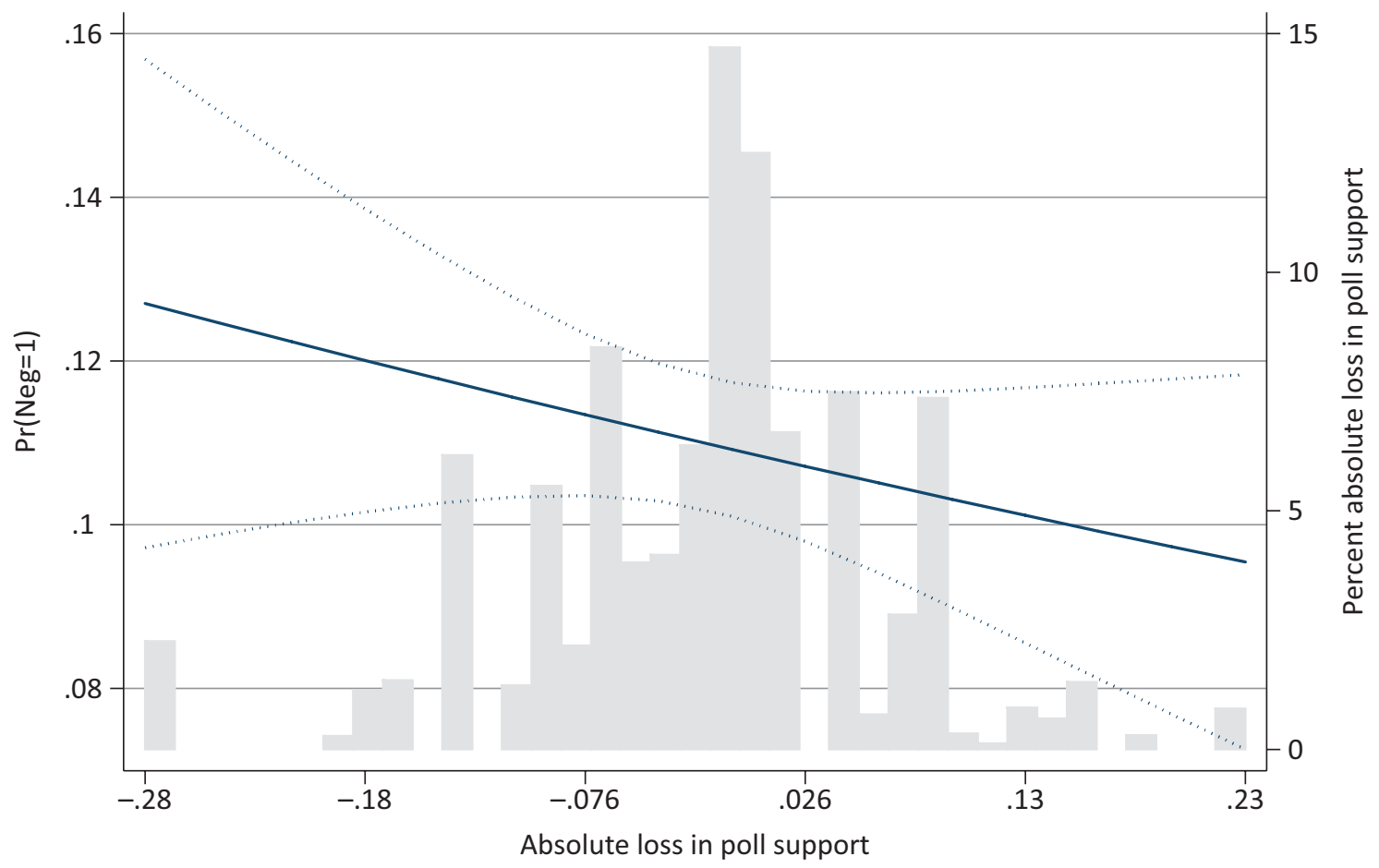

Coefficient POLLsupportLOST $=-.63$ z-statistic $=-1.24$

Figure 4. Negative campaigning by percentage of support lost between polls, marginal effects. Notes: Marginal effects with $95 \%$ confidence intervals, based on coefficients in model M5 (Table 3 ). The grey bars represent the distribution of the variable "absolute loss in poll support" (percentage histogram).

Our data does not, of course, allow us to test for the underlying emotional components of such effects. We do not have data that measure the emotional state of campaign managers, nor do we know how they actually reacted to the publication of poll results; we do not know if seeing a drop in poll support makes them more attentive to potential risks associated with more aggressive communication strategies. We do not even know who makes the decision ultimately to go negative on the opponents. The realm of strategic decisions of campaign consultants 


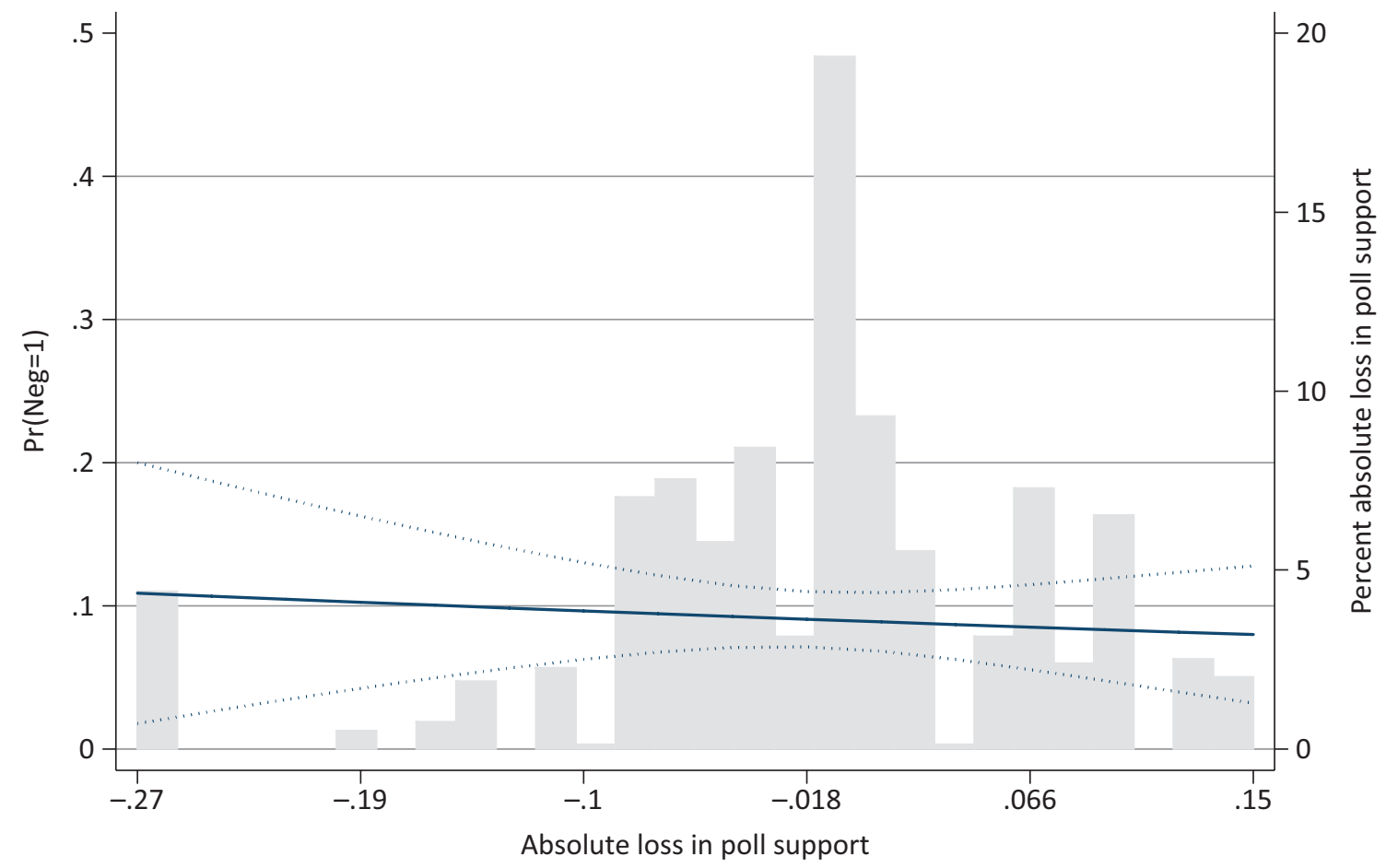

Coefficient POLLsupportLOST $=-.872$ z-statistic $=-.44$

(a)

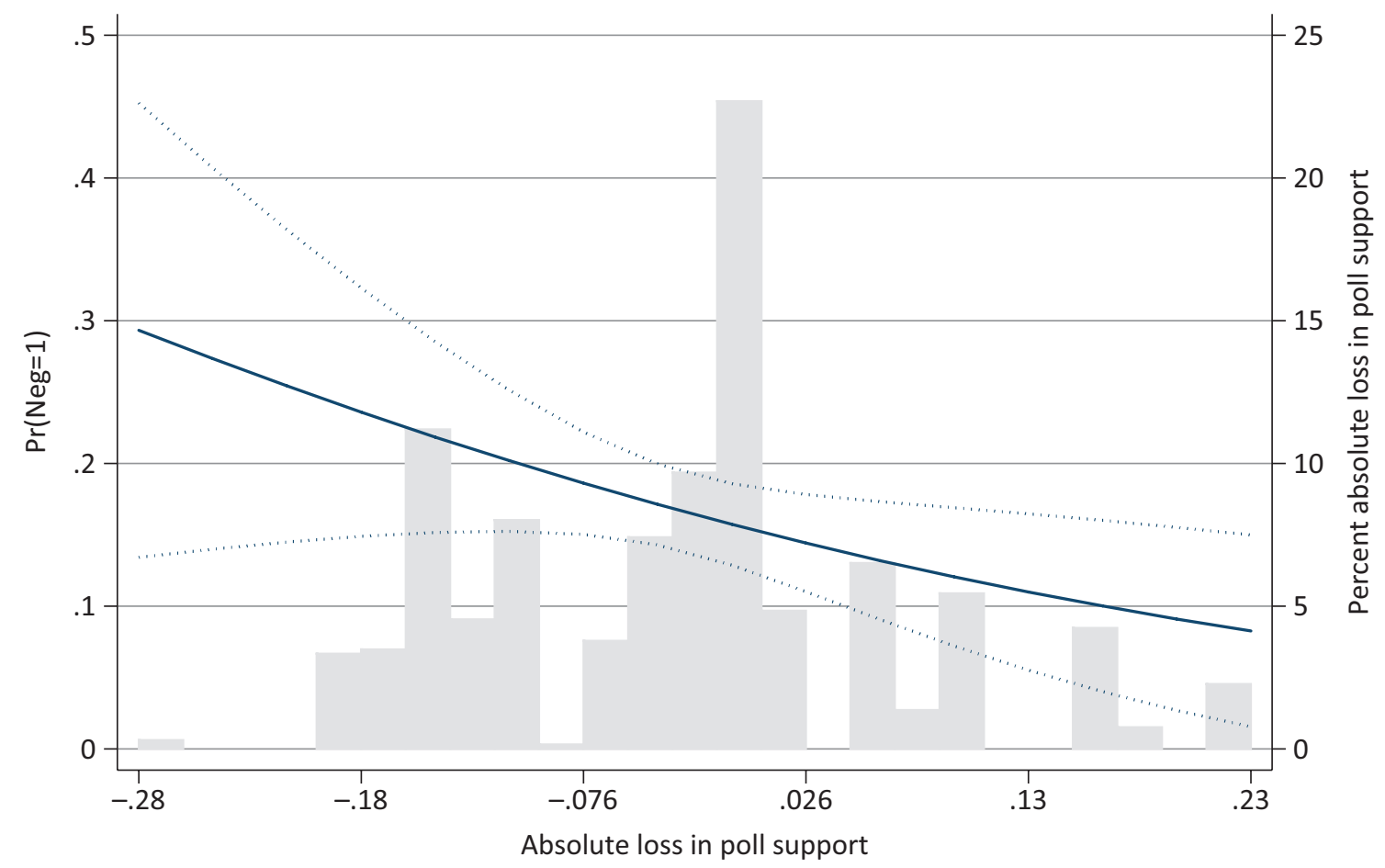

Coefficient POLLsupportLOST $=-3.264$ z-statistic $=-1.87$

(b)

Figure 5. Negative campaigning by percentage of support lost between polls, marginal effects (winning vs. losing in polls). (a) Winning in polls during week 4. (b) Losing in polls during week 4 . Notes: marginal effects with $95 \%$ confidence intervals, based on coefficients in model M6 (top panel) and M7 (bottom panel) of Table 3. All estimations computed for ads published within the last week of the campaign; top panel presents estimations for ads published by the camp winning in the polls (regardless of evolution of poll support), whereas bottom panel presents estimations for ads published by the camp losing in the polls (regardless of evolution of poll support). 
and PR managers is, in our case, hidden inside the black box of campaign strategies. All in all, our results can be read as follows: Frontrunners do not go negative, especially not when they only have a little time left before the vote (why would they, after all? They are already ahead in the race and attack messages can be a risky business). Underdogs, on the other hand, are more likely to go negative, especially when they have nothing to lose (in which case they "pull the goalie"). This asymmetry between runners, that grows stronger as time to campaign runs out, holds in most situations but one: when underdogs see their position in the polls deteriorate drastically they would rather not use personal attacks.

\section{Conclusion and Discussion}

It seems today undeniable that attack politics matter. It is usually disliked by citizens, and might thus contribute to some of the systemic illnesses of Western electoral democracies, such as low turnout (Ansolabehere \& lyengar, 1995) and increased cynicism (Yoon et al., 2005). It might, on the other hand, increase citizens' attention (Geer, 2006; Lau \& Redlawsk, 2015). Perhaps more importantly, attacks have the potential of being electorally consequential as they might reduce positive feelings for the target (Banda \& Windett, 2016; Nai \& Seeberg, 2018; Pinkleton, 1997). Within this framework, it is thus not a surprise that most studies on the reasons to go negative have focussed on the strategic underpinnings of such decision, focussing on the trade-off between benefits (decreasing support and turnout for the opponent, discouraging undecided voters to turn out and vote for the opponents, and ultimately win the race) and costs (potential "backlash" effects coming from voters usually disliking negative messages). Two factors seem to stand out as particularly relevant: the competitive standing of actors and the advertisement timing. Existing literature rather strongly agrees that the prospect of electoral failure increases the use of negative advertising (e.g., Harrington \& Hess, 1996; Skaperdas \& Grofman, 1995) and that the frequency of negative messages seems to increase when voting day looms (e.g., Freedman \& Goldstein, 2002; Ridout \& Holland, 2010).

The existence of those dynamics was our starting point. In this article, we studied campaign dynamics on a particularly conservative case (Swiss referenda), but by focussing on a particular type of campaign messages that are more likely to backfire and lower evaluation of the sponsor: personal attacks (Budesheim et al., 1996). Our preliminary goal was to confirm, for this specific case as well, the known effects of competitive standing and advertisement timing. Our results show that, indeed, personal attacks are more likely when actors are lagging behind in the polls and when voting day is close.

Beyond replicating these effects, however, our goal was to advance our understanding about strategic dynamics by testing two new hypotheses, that we named the frantic loser and the anxiety hypotheses. We pro- vided preliminary support for these hypotheses. Our analyses show that frontrunners go negative very rarely, especially when they only have a little time to recover from potential faux pas. On the other hand, underdogs are sensibly more likely to go negative, especially when they have nothing to lose and time to campaign runs out. Our analyses also showed, in support of our anxiety hypothesis, that when underdogs see their position in the polls deteriorate they are less likely to use personal attacks.

We postulated that this effect might exist due to the intervention of forces that go beyond (and beneath) pure rationality and strategic reasoning: emotional states, in this case anxiety experienced when facing drastic degradation of competitive standings. Due to the nature of our data, the intervening and moderating effect of emotions is only postulated here. Our analyses do, however, provide evidence that supports this rationale. All in all, our results suggest that a more encompassing approach is needed for the study of the drivers of negativity: first, by adding a dynamic component and acknowledging that campaigns are highly volatile and evolving social phenomena, and second by acknowledging that pure rational thought and economic strategies are necessarily affected by the underlying emotional states of those, humans after all, that face the decision whether or not to run negative ads. Correlational effects such as those described in this study should thus, as a next step, be tested through sociological studies of actors involved in strategic campaign decisions (e.g., Levenshus, 2010; Plasser, 2000).

\section{Acknowledgments}

A previous version of this article has been presented at the World Congress of the International Political Science Association, Poznan, July 23-28 2016, in the panel "Negative Campaigning Across the World: Towards A General Theory". We are very grateful to all the participants in the panel and to Dick Johnston, Jeff Karp, Pippa Norris, and Felipe Borba for their precious inputs. All remaining errors are of course our responsibility alone. Thank you to Gfs.bern for providing the SRG data. Alessandro Nai acknowledges financial support from the Swiss National Science Foundation (SNSF ref: 100017_137695) and logistic support from the Electoral Integrity Project (University of Sydney and Harvard). Many thanks also to Elizabeth Young for valuable inputs and editing.

\section{Conflict of Interests}

The authors declare no conflict of interests.

\section{References}

Ansolabehere, S., \& lyengar, S. (1995). Going negative: How attack ads shrink and polarize the electorate. New York, NY: Free Press. 
Banda, K. K., \& Windett, J. H. (2016). Negative advertising and the dynamics of candidate support. Political Behavior, 38(3), 747-766.

Benoit, W. L. (1999). Seeing spots: A functional analysis of presidential television advertisements from 1952-1996. New York, NY: Praeger.

Bernhard, L. (2012). Campaign strategy in direct democracy. Basingstoke: Palgrave Macmillan.

Blackwell, M. (2013). A framework for dynamic causal inference in political science. American Journal of Political Science, 57(2), 504-520.

Brader, T. (2006). Campaigning for hearts and minds: How emotional appeals in political ads work. Chicago, MI: University of Chicago Press.

Broh, C. A. (1980). Horse-race journalism: Reporting the polls in the 1976 presidential election. Public Opinion Quarterly, 44(4), 514-529.

Brooks, D. J., \& Murov, M. (2012). Assessing accountability in a post-Citizens United era: The effects of attack ad sponsorship by unknown independent groups. American Political Research, 40(3), 383-418.

Budesheim, T. L., Houston, D. A., \& DePaola, S. G. (1996). Persuasiveness of in-group and out-group political messages: The case of negative campaigning. Journal of Personality and Social Psychology, 70(3), 523-534.

Carraro, L., \& Castelli, L. (2010). The implicit and explicit effects of negative political campaigns: Is the source really blamed? Political Psychology, 31(4), 617-645.

Damasio, A. (1994), Descartes' error: Emotion, reason, and the human brain. New York, NY: Penguin.

Damore, D. F. (2002). Candidate strategy and the decision to go negative. Political Research Quarterly, 55(3), 669-685.

Elmelund-Præstekær, C. (2010). Beyond American negativity: Toward a general understanding of the determinants of negative campaigning. European Political Science Review, 2(1), 137-156.

Elmelund-Præstekær, C. (2011). Issue ownership as a determinant of negative campaigning. International Political Science Review, 32(2), 209-221.

Freedman, P., \& Goldstein, K. (2002). Lessons learned campaign advertising in the 2000 elections. Political Communication, 19(1), 5-28.

Fridkin, K. L., \& Kenney, P. J. (2011). Variability in citizens' reactions to different types of negative campaigns. American Journal of Political Science, 55(2), 307-325.

Garramone, G. M. (1984). Voter response to negative political ads. Journalism Quarterly, 61(2), 250-259.

Geer, J. G. (2006). In defense of negativity: Attack ads in presidential campaigns. Chicago, MI: University of Chicago Press.

Geer, J. G. (2012). The news media and the rise of negativity in presidential campaigns. PS: Political Science \& Politics, 45(3), 422-427.

Hänggli, R., \& Häusermann, S. (2015). Consensus lost? Disenchanted democracy in Switzerland. Swiss Political Science Review, 21(4), 475-490.

Hänggli, R., \& Kriesi, H. (2010). Political framing strate- gies and their impact on media framing in a Swiss direct-democratic campaign. Political Communication, 27(2), 141-157.

Harrington, J., \& Hess, G. (1996). A spatial theory of positive and negative campaigning. Games and Economic Behavior, 17(2), 209-229.

Haynes, A. A., \& Rhine, S. L. (1998). Attack politics in presidential nomination campaigns: An examination of the frequency and determinants of intermediated negative messages against opponents. Political Research Quarterly, 51(3), 691-721.

Huddy, L., Feldman, S., Taber, C., \& Lahav, G. (2005). Threat, anxiety, and support of antiterrorism policies. American Journal of Political Science, 49(3), 593-608.

Iyengar, S., Norpoth, H., \& Hahn, K. S. (2004). Consumer demand for election news: The horserace sells. The Journal of Politics, 66(1), 157-175.

Johnson-Cartee, K. S., \& Copeland, G. A. (1991). Negative political advertising: Coming of age. Hillsdale, NJ: Lawrence Erlbaum.

Kriesi, H. (2005). Direct democratic choice. The Swiss experience. Oxford: Lexington Books.

Kriesi, H. (2006). Role of the political elite in Swiss directdemocratic votes. Party Politics, 12(5), 599-622.

Lanz, S., \& Nai, A. (2015). Vote as you think: Determinants of consistent decision-making in direct democracy. Swiss Political Science Review, 21(1), 119-139.

Lau, R. R. (1982). Negativity in political perception. Political Behavior, 4(4), 353-377.

Lau, R. R., \& Pomper, G. M. (2004). Negative campaigning: An analysis of U.S. senate elections. Oxford: Rowman and Littlefield.

Lau, R. R., \& Redlawsk, D. P. (2015). The effects of advertising tone on information processing and vote choice. In A. Nai \& A. S. Walter (Eds.), New perspectives on negative campaigning: Why attack politics matters (pp. 249-266). Colchester: ECPR Press.

Lau, R. R., Siegelman, L., \& Rovner, I. B. (2007). The effects of negative political campaigns: A metaanalytic reassessment. The Journal of Politics, 69(4), 1176-1209.

Lerner, J. S., \& Keltner, D. (2001). Fear, anger, and risk. Journal of Personality and Social Psychology, 81(1), 146-159.

Levenshus, A. (2010). Online relationship management in a presidential campaign: A case study of the Obama campaign's management of its internetintegrated grassroots effort. Journal of Public Relations Research, 22(3), 313-335.

MacKuen, M., Marcus, G. E., Neuman, W. R., \& Keele, L. (2007). The third way: The theory of affective intelligence and American democracy. In R. Neuman, G. E. Marcus, A. Crigler, \& M. B. MacKuen (Eds.), The affect effect. Dynamics of emotion in political thinking and behavior (pp. 124-151). Chicago, MI: The University of Chicago Press.

Marcus, G. E. (2000). Emotions in politics. Annual Review of Political Science, 3(1), 221-250. 
Marcus, G. E. (2002). The sentimental citizen. Emotion in democratic politics. University Park, PA: The Pennsylvania State University.

Marcus, G. E., \& MacKuen, M. B. (1993). Anxiety, enthusiasm, and the vote: The emotional underpinnings of learning and involvement during presidential campaigns. American Political Science Review, 87(3), 672-685.

Marcus, G. E., Neuman, R., \& MacKuen, M. B. (2000). Affective intelligence and political judgement. Chicago, MI: The University of Chicago Press.

Marquis, L., \& Bergman, M. M. (2009). Development and consequences of referendum campaigns in Switzerland, 1981-1999. Swiss Political Science Review, 15(1), 63-97.

Marsh, C. (1985). Back on the bandwagon: The effect of opinion polls on public opinion. British Journal of Political Science, 15(1), 51-74.

Nai, A. (2013). What really matters is which camp goes dirty. Differential effects of negative campaigning on turnout during Swiss federal ballots. European Journal of Political Research, 52(1), 44-70.

Nai, A. (2014). The cadillac, the mother-in-law, and the ballot: Individual and contextual roots of ambivalence in Swiss direct democracy. Electoral Studies, 33, 292-306.

Nai, A. (2015). The maze and the mirror: Voting correctly in direct democracy. Social Science Quarterly, 96(2), 465-486.

Nai, A., \& Sciarini, P. (2018). Why 'going negative'? Strategic and situational determinants of personal attacks in Swiss direct democratic votes. Journal of Political Marketing, 17(4). https://doi.org/10.1080/ 15377857.2015.1058310

Nai, A., \& Seeberg, H. B. (2018). A series of persuasive events. Sequencing effects of negative and positive messages on party evaluations and perceptions of negativity. Journal of Marketing Communications, 24(4), 412-432.

Nai, A., Schemeil, Y., \& Marie, J. L. (2017). Anxiety, sophistication, and resistance to persuasion: Evidence from a quasi-experimental survey on global climate change. Political Psychology, 38(1), 137-156.

Nai, A., \& Walter, A. S. (2015) (Eds.). New perspectives on negative campaigning: Why attack politics matters. Colchester: ECPR Press.
Peterson, D. A., \& Djupe, P. A. (2005). When primary campaigns go negative: The determinants of campaign negativity. Political Research Quarterly, 58(1), 45-54.

Pinkleton, B. (1997). The effects of negative comparative political advertising on candidate evaluations and advertising evaluations: An exploration. Journal of $\mathrm{Ad}$ vertising, 26(1), 19-29.

Plasser, F. (2000). American campaign techniques worldwide. The Harvard International Journal of Press/Politics, 5(4), 33-54.

Ridout, T. N., \& Holland, J. L. (2010). Candidate strategies in the presidential nomination campaign. Presidential Studies Quarterly, 40(4), 611-630.

Roese, N. J., \& Sande, G. N. (1993). Backlash effects in attack politics. Journal of Applied Social Psychology, 23(8), 632-653.

Rothschild, D., \& Malhotra, N. (2014). Are public opinion polls self-fulfilling prophecies? Research \& Politics, 1(2). https://doi.org/10.1177\%2F20531680 14547667

Sciarini, P., \& Tresch, A. (2011). Campaign effects in direct-democratic votes in Switzerland. Journal of Elections, Public Opinion and Parties, 21(3), 333-357.

Skaperdas, S., \& Grofman, B. (1995). Modeling negative campaigning. American Political Science Review, 89(1), 49-61.

Steenbergen, M. R., \& Ellis, C. (2006). Fear and loathing in American elections: Context, traits, and negative candidate affect. In D. P. Redlawsk (Ed.), Feeling politics. Emotion in political information processing (pp. 109-133). New York, NI: Palgrave.

Vandello, J. A., Goldschmied, N. P., \& Richards, D. A. (2007). The appeal of the underdog. Personality and Social Psychology Bulletin, 33(12), 1603-1616.

Walter, A. S. (2012). Negative campaigning in Western Europe. Beyond the vote-seeking perspective. Zutphen: Wöhrmann.

Walter, A. S., van der Brug, W., \& van Praag, P. (2014). When the stakes are high: Party competition and negative campaigning. Comparative Political Studies, 47(4), 550-573.

Yoon, K., Pinkleton, B. E., \& Ko, W. (2005). Effects of negative political advertising on voting intention: An exploration of the roles of involvement and source credibility in the development of voter cynicism. Journal of Marketing Communications, 11(2), 95-112.

\section{About the Authors}

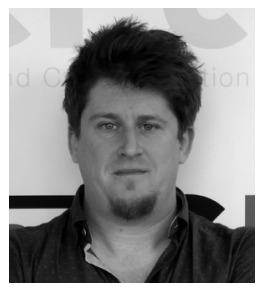

Alessandro Nai is Assistant Professor of Political Communication and Journalism at the Department of Communication Science, University of Amsterdam. His recent work has been published in journals such as Political Psychology, European Journal of Political Research, West European Politics, Government \& Opposition, European Political Science, Personality and Individual Differences, Presidential Studies Quarterly, Electoral Studies, Journal of Political Marketing, and more. He recently co-edited the volumes New Perspectives on Negative Campaigning: Why Attack Politics Matters (ECPR Press, 2015, with Annemarie S. Walter) and Election Watchdogs (Oxford University Press, 2017, with Pippa Norris). He is currently Associated Editor of the Journal of Social and Political Psychology. 


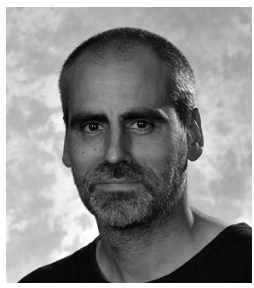

Ferran Martínez i Coma is Lecturer at the Center for Governance and Public Policy, Griffith University. Previously he was Senior Research Associate at the Electoral Integrity Project at the University of Sydney. His research has focused on electoral behaviour, electoral integrity, and political parties. He has published, among others, in Electoral Studies, Party Politics, West European Politics, Government and Opposition, Presidential Studies Quarterly and the European Journal of Political Research. 


\section{Appendix}

Table A1. List of referenda between 1999 and 2012 at the Swiss federal level.

\begin{tabular}{|c|c|c|c|c|c|}
\hline $\begin{array}{l}\text { Ref. } \\
\text { ID }\end{array}$ & Referendum issue & Date voted & Type & $\begin{array}{l}\text { Percentage } \\
\text { of ads with } \\
\text { attacks }\end{array}$ & $\begin{array}{l}\text { SRG } \\
\text { survey } \\
\text { available? }\end{array}$ \\
\hline 661 & Federal Council membership eligibility & 07.02.1999 & Compulsory referendum & 0.00 & No \\
\hline 662 & House ownership for everyone & 07.02 .1999 & Initiative & 0.34 & No \\
\hline 663 & Spatial planning law amendment & 07.02 .1999 & Optional referendum & 0.00 & No \\
\hline 664 & Organ transplantation regulations & 07.02.1999 & Compulsory referendum & No ads & No \\
\hline 671 & New Swiss constitution & 18.04.1999 & Compulsory referendum & 0.10 & No \\
\hline 681 & Asylum law & 13.06.1999 & Optional referendum & 0.05 & No \\
\hline 682 & Federal resolution on foreigners and asylum & 13.06.1999 & Optional referendum & 0.05 & No \\
\hline 683 & Medical prescription of heroin & 13.06.1999 & Optional referendum & 0.00 & No \\
\hline 684 & Federal law on disability insurance & 13.06.1999 & Optional referendum & 0.00 & No \\
\hline 685 & Federal law on maternity insurance & 13.06.1999 & Optional referendum & 0.32 & Yes \\
\hline 691 & Judicial reform & 12.03 .2000 & Compulsory referendum & 0.00 & No \\
\hline 692 & Speeding up direct democracy & 12.03 .2000 & Initiative & 0.22 & No \\
\hline 693 & Women in federal authorities & 12.03 .2000 & Initiative & 0.00 & No \\
\hline 694 & Procreation technology & 12.03 .2000 & Initiative & 0.00 & No \\
\hline 695 & Halving motorised road traffic & 12.03 .2000 & Initiative & 0.12 & No \\
\hline 701 & Sectoral agreements with the EU & 21.05 .2000 & Optional referendum & 0.12 & No \\
\hline 711 & Promoting solar energy & 24.09.2000 & Initiative & 0.00 & Wave 1 only \\
\hline 712 & Counter-proposal on solar energy & 24.09 .2000 & Counter-proposal & 0.00 & Wave 1 only \\
\hline 713 & Tax contribution for energy efficiency & 24.09 .2000 & Compulsory referendum & 0.00 & Wave 1 only \\
\hline 714 & Regulating immigration & 24.09 .2000 & Initiative & 0.27 & Yes \\
\hline 715 & Referendums with counter-proposals & 24.09 .2000 & Initiative & 0.00 & No \\
\hline 721 & Retirement age for women & 26.11 .2000 & Initiative & 0.13 & No \\
\hline 722 & Flexible retirement age & 26.11 .2000 & Initiative & 0.16 & No \\
\hline 723 & Economising on military and defence & 26.11 .2000 & Initiative & 0.02 & No \\
\hline 724 & Lower hospital expenses & 26.11 .2000 & Initiative & 0.20 & No \\
\hline 725 & Law on federal employees & 26.11 .2000 & Optional referendum & 0.00 & No \\
\hline 731 & European Union membership & 04.03 .2001 & Initiative & 0.07 & Yes \\
\hline 732 & Lower medicine prices & 04.03 .2001 & Initiative & 0.11 & No \\
\hline 731 & European Union membership & 04.03 .2001 & Initiative & 0.07 & Yes \\
\hline 732 & Lower medicine prices & 04.03 .2001 & Initiative & 0.11 & No \\
\hline 733 & Urban speed limit of $30 \mathrm{~km} / \mathrm{h}$ & 04.03 .2001 & Initiative & 0.03 & No \\
\hline 741 & Federal law on the military amendment (1) & 10.06.2001 & Optional referendum & 0.26 & Yes \\
\hline 742 & Federal law on the military amendment (2) & 10.06.2001 & Optional referendum & 0.26 & Yes \\
\hline 743 & Abolishing permits for creating diocese & 10.06 .2001 & Compulsory referendum & 0.00 & No \\
\hline 751 & Federal resolution on expenditure & 02.12 .2001 & Compulsory referendum & 0.00 & No \\
\hline 752 & For an assured Aged and Bereaved insurance & 02.12 .2001 & Initiative & 0.05 & No \\
\hline
\end{tabular}


Table A1. (Cont.) List of referenda between 1999 and 2012 at the Swiss federal level.

\begin{tabular}{|c|c|c|c|c|c|}
\hline $\begin{array}{l}\text { Ref. } \\
\text { ID }\end{array}$ & Referendum issue & Date voted & Type & $\begin{array}{l}\text { Percentage } \\
\text { of ads with } \\
\text { attacks }\end{array}$ & $\begin{array}{l}\text { SRG } \\
\text { survey } \\
\text { available? }\end{array}$ \\
\hline 753 & For an authentic security policy & 02.12 .2001 & Initiative & 0.16 & No \\
\hline 754 & Solidarity creates security & 02.12 .2001 & Initiative & 0.15 & No \\
\hline 755 & For a capital gains tax & 02.12 .2001 & Initiative & 0.08 & No \\
\hline 761 & United Nations membership & 03.03.2002 & Initiative & 0.17 & Yes \\
\hline 762 & Reducing working hours & 03.03.2002 & Initiative & 0.06 & No \\
\hline 771 & Amendment on abortion & 02.06 .2002 & Optional referendum & 0.00 & Yes \\
\hline 772 & Restricting abortion & 02.06 .2002 & Initiative & 0.17 & Yes \\
\hline 781 & Surplus gold reserves into pension fund & 22.09.2002 & Initiative & 0.02 & Yes \\
\hline 782 & Counter-proposal on gold reserves & 22.09.2002 & Counter-proposal & 0.00 & Yes \\
\hline 783 & Electricity market law & 22.09.2002 & Optional referendum & 0.02 & No \\
\hline 791 & Restricting asylum policies & 24.11.2002 & Initiative & 0.26 & Yes \\
\hline 792 & Federal law on unemployment insurance & 24.11.2002 & Optional referendum & 0.05 & No \\
\hline 801 & Referendum process & 09.02.2003 & Compulsory referendum & 0.00 & No \\
\hline 802 & Cantonal contribution to hospital medicine & 09.02 .2003 & Optional referendum & 0.00 & No \\
\hline 811 & Federal law on the army & 18.05.2003 & Optional referendum & 0.06 & No \\
\hline 812 & Federal law on civil defence & 18.05.2003 & Optional referendum & 0.08 & No \\
\hline 813 & Motor vehicle-free Sundays & 18.05.2003 & Initiative & 0.03 & No \\
\hline 814 & Affordable healthcare & 18.05 .2003 & Initiative & 0.05 & Yes \\
\hline 815 & Equal rights for the disabled & 18.05 .2003 & Initiative & 0.00 & No \\
\hline 816 & Fair rents & 18.05 .2003 & Initiative & 0.07 & No \\
\hline 817 & Electricity without nuclear power & 18.05 .2003 & Initiative & 0.20 & No \\
\hline 818 & Ban on new nuclear power plants & 18.05 .2003 & Initiative & 0.20 & No \\
\hline 819 & Provision of vocational education & 18.05.2003 & Initiative & 0.00 & No \\
\hline 821 & Counter-proposals to motorway initiative & 08.02 .2004 & Counter-proposal & 0.13 & Yes \\
\hline 822 & Amendment to the Obligations (tenancy) law & 08.02 .2004 & Optional referendum & 0.06 & No \\
\hline 823 & Life sentences for dangerous criminals & 08.02 .2004 & Initiative & 0.00 & No \\
\hline 831 & $\begin{array}{l}\text { Amending the Aged and Bereaved insurance } \\
\text { law }\end{array}$ & 16.05 .2004 & Optional referendum & 0.03 & No \\
\hline 832 & Financing of Aged and Bereaved insurance & 16.05.2004 & Compulsory referendum & 0.00 & No \\
\hline 833 & Federal law on taxation & 16.05 .2004 & Optional referendum & 0.07 & No \\
\hline 841 & Federal resolution on naturalisation & 26.09.2004 & Compulsory referendum & 0.03 & Yes \\
\hline 842 & $\begin{array}{l}\text { Citizenship rights of third-generation } \\
\text { immigrants }\end{array}$ & 26.09.2004 & Compulsory referendum & 0.02 & Yes \\
\hline 843 & $\begin{array}{l}\text { Compensation for members of the armed } \\
\text { forces }\end{array}$ & 26.09.2004 & Optional referendum & 0.00 & Yes \\
\hline 844 & Postal services for all & 26.09.2004 & Initiative & 0.00 & No \\
\hline 851 & Federal and cantonal financial duties & 28.11 .2004 & Compulsory referendum & 0.00 & Yes \\
\hline 852 & $\begin{array}{l}\text { Constitutional reordering of the federal } \\
\text { budget }\end{array}$ & 28.11.2004 & Compulsory referendum & No ads & No \\
\hline
\end{tabular}


Table A1. (Cont.) List of referenda between 1999 and 2012 at the Swiss federal level.

\begin{tabular}{|c|c|c|c|c|c|}
\hline $\begin{array}{l}\text { Ref. } \\
\text { ID }\end{array}$ & Referendum issue & Date voted & Type & $\begin{array}{l}\text { Percentage } \\
\text { of ads with } \\
\text { attacks }\end{array}$ & $\begin{array}{l}\text { SRG } \\
\text { survey } \\
\text { available? }\end{array}$ \\
\hline 853 & Stem cell research law & 28.11.2004 & Optional referendum & 0.00 & Yes \\
\hline 871 & Schengen/Dublin Agreement & 05.06 .2005 & Optional referendum & 0.13 & Yes \\
\hline 872 & Registered partnerships & 05.06 .2005 & Optional referendum & 0.00 & Wave 1 only \\
\hline 881 & Agreement on free movement of persons & 25.09 .2005 & Optional referendum & 0.16 & Yes \\
\hline 891 & Genetically modified food & 27.11.2005 & Compulsory referendum & 0.00 & Yes \\
\hline 892 & Labour law & 27.11.2005 & Optional referendum & 0.00 & Yes \\
\hline 901 & Constitutional amendment on education & 21.05 .2006 & Compulsory referendum & No ads & No \\
\hline 911 & Swiss National Bank profits & 24.09 .2006 & Initiative & 0.06 & Yes \\
\hline 912 & Amendment to the foreigners law & 24.09 .2006 & Optional referendum & 0.09 & Yes \\
\hline 913 & Amendment to the asylum law & 24.09 .2006 & Optional referendum & 0.08 & Yes \\
\hline 921 & Law on assistance for eastern Europe & 26.11.2006 & Optional referendum & 0.10 & Yes \\
\hline 922 & Amendment to the family allowances law & 26.11.2006 & Optional referendum & 0.04 & Yes \\
\hline 931 & For a Social Unified Health Insurance & 11.03.2007 & Initiative & 0.07 & Yes \\
\hline 941 & Disability law amendment & 17.06.2007 & Optional referendum & 0.01 & Yes \\
\hline 951 & $\begin{array}{l}\text { Against fighter aircraft noise in tourism } \\
\text { areas }\end{array}$ & 24.02.2008 & Initiative & 0.00 & Wave 1 only \\
\hline 952 & Business tax reform & 24.02 .2008 & Optional referendum & 0.04 & Wave 1 only \\
\hline 961 & For democratic naturalisation & 01.06 .2008 & Initiative & 0.44 & Yes \\
\hline 962 & $\begin{array}{l}\text { Against government run information } \\
\text { campaigns }\end{array}$ & 01.06 .2008 & Initiative & 0.88 & Yes \\
\hline 963 & Counter-proposal on health insurance & 01.06 .2008 & Counter-proposal & 0.10 & Yes \\
\hline 971 & Pornographic crimes against children & 30.11 .2008 & Initiative & 0.00 & No \\
\hline 972 & Flexible state pension age & 30.11 .2008 & Initiative & 0.09 & Yes \\
\hline 973 & $\begin{array}{l}\text { Restriction of the right of associations to } \\
\text { appeal against building projects }\end{array}$ & 30.11 .2008 & Initiative & 0.04 & Yes \\
\hline 974 & $\begin{array}{l}\text { Legalisation of the personal consumption } \\
\text { and production of cannabis }\end{array}$ & 30.11 .2008 & Initiative & 0.03 & Yes \\
\hline 975 & Revision of the federal statute on narcotics & 30.11 .2008 & Optional referendum & 0.05 & Yes \\
\hline 981 & $\begin{array}{l}\text { Extending freedom of movement for } \\
\text { workers in EU to Bulgaria and Romania }\end{array}$ & 08.02 .2009 & Optional referendum & 0.08 & Yes \\
\hline 991 & Future with complementary medicine & 17.05.2009 & Counter-proposal & 0.00 & Yes \\
\hline 992 & Introduction of biometric passports & 17.05.2009 & Optional referendum & 0.00 & Yes \\
\hline 1001 & $\begin{array}{l}\text { Limited increase of VAT to continue } \\
\text { financing the Disability Insurance }\end{array}$ & 27.09.2009 & Compulsory referendum & 0.02 & Yes \\
\hline 1002 & Decision not to introduce public initiatives & 27.09.2009 & Compulsory referendum & No ads & Yes \\
\hline 1011 & Aviation fuel taxation & 29.11.2009 & Compulsory referendum & 0.00 & Yes \\
\hline 1012 & Ban on exporting war supplies & 29.11.2009 & Initiative & 0.00 & Yes \\
\hline 1013 & Ban on the construction of new minarets & 29.11.2009 & Initiative & 0.20 & Yes \\
\hline 1021 & $\begin{array}{l}\text { Amendment to the constitution on } \\
\text { research on humans }\end{array}$ & 07.03 .2010 & Compulsory referendum & No ads & Wave 1 only \\
\hline
\end{tabular}


Table A1. (Cont.) List of referenda between 1999 and 2012 at the Swiss federal level.

\begin{tabular}{|c|c|c|c|c|c|}
\hline $\begin{array}{l}\text { Ref. } \\
\text { ID }\end{array}$ & Referendum issue & Date voted & Type & $\begin{array}{l}\text { Percentage } \\
\text { of ads with } \\
\text { attacks }\end{array}$ & $\begin{array}{l}\text { SRG } \\
\text { survey } \\
\text { available? }\end{array}$ \\
\hline 1022 & $\begin{array}{l}\text { Providing enhanced legal protection for } \\
\text { animals }\end{array}$ & 07.03.2010 & Initiative & 0.06 & Wave 1 only \\
\hline 1023 & $\begin{array}{l}\text { Change in minimum conversion rate for } \\
\text { occupational/disability pension plans }\end{array}$ & 07.03.2010 & Optional referendum & 0.15 & Wave 1 only \\
\hline 1031 & Revision of unemployment benefits & 26.09.2010 & Optional referendum & 0.09 & Yes \\
\hline 1041 & For the deportation of criminal foreigners & 28.11.2010 & Initiative & 0.00 & Yes \\
\hline 1042 & $\begin{array}{l}\text { Counter-proposal to the initiative for the } \\
\text { deportation of criminal foreigners }\end{array}$ & 28.11.2010 & Counter-proposal & 0.15 & Yes \\
\hline 1043 & Taxation justice initiative & 28.11.2010 & Initiative & 0.20 & Yes \\
\hline 1051 & For the protection against gun violence & 13.02.2011 & Initiative & 0.15 & Yes \\
\hline 1061 & $\begin{array}{l}\text { For an end to the limitless construction of } \\
\text { second homes }\end{array}$ & 11.03.2012 & Initiative & 0.04 & Yes \\
\hline 1062 & $\begin{array}{l}\text { For tax-supported building society savings } \\
\text { to buy living space for self-use }\end{array}$ & 11.03.2012 & Initiative & 0.00 & Yes \\
\hline 1063 & Six weeks of vacation for everyone & 11.03.2012 & Initiative & 0.00 & Yes \\
\hline 1064 & $\begin{array}{l}\text { State earnings from gambling to be used for } \\
\text { the public interest }\end{array}$ & 11.03.2012 & Compulsory referendum & 0.00 & Yes \\
\hline 1065 & $\begin{array}{l}\text { Re-introduction of the Fixed Book Price } \\
\text { Agreement }\end{array}$ & 11.03.2012 & Optional referendum & 0.00 & Yes \\
\hline 1071 & For assistance with savings for home buyers & 17.06.2012 & Initiative & 0.01 & Yes \\
\hline 1072 & $\begin{array}{l}\text { For strengthening popular rights on } \\
\text { foreign policy }\end{array}$ & 17.06.2012 & Initiative & 0.00 & Yes \\
\hline 1073 & Reform of healthcare legislation & 17.06.2012 & Optional referendum & 0.00 & Yes \\
\hline 1081 & $\begin{array}{l}\text { Counter-project to initiative "youth } \\
\text { and music" }\end{array}$ & 23.09.2012 & Counter-proposal & 0.00 & Yes \\
\hline 1082 & Secure housing in old age & 23.09.2012 & Initiative & 0.03 & Yes \\
\hline 1083 & Smoking ban referendum & 23.09.2012 & Initiative & 0.06 & Yes \\
\hline 1091 & Swiss Animal Diseases Act & 25.11.2012 & Optional referendum & 0.00 & No \\
\hline
\end{tabular}

Notes: Referenda excluded from all analyses if SRG survey data missing, and from some analyses if only wave 1 is available. Source: authors' own data (share of negative ads) and Gfs.bern data (pre-election polls). 